\title{
Accurate and precise
}

quantification of major and trace

element compositions of calcic-

sodic fluid inclusions by combined

microthermometry and LA-ICPMS

analysis

\section{Journal Article}

Author(s):

Schlegel, Tobias U.; Wälle, Markus; Steele-Maclnnis, Mathew; Heinrich, Christoph A. (D)

Publication date:

2012-12

Permanent link:

https://doi.org/10.3929/ethz-b-000061736

Rights / license:

Creative Commons Attribution-NonCommercial-NoDerivatives 4.0 International

Originally published in:

Chemical Geology 334, https://doi.org/10.1016/j.chemgeo.2012.10.001 
This is the Green Open Access version of: Schlegel, T. U., Wälle, M., Steele-MacInnis, M. and Heinrich, C. A. (2012). Chemical Geology, vol. 334, p. 144-153 made available through researchcollection.ethz.ch Original publication see http://dx.doi.org/10.1016/j.chemgeo.2012.10.001

\title{
Accurate and precise quantification of major and trace element compositions of calcic-sodic fluid inclusions by combined microthermometry and LA-ICPMS analysis
}

\author{
Tobias U.Schlegel1, Markus Wälle', Mathew Steele-MacInnis ${ }^{2}$, and Christoph A. Heinrich1 \\ ${ }^{1}$ Institute of Geochemistry and Petrology, ETH Zurich, 8092 Zurich, Switzerland \\ 2Department of Geosciences, Virginia Tech, Blacksburg, VA 24061, USA \\ Corresponding Author: \\ Tobias U. Schlegel \\ Affiliation: Institute of Geochemistry and Petrology, ETH Zurich, Switzerland \\ Address: NW D87, Clausiusstrasse 25, 8092 Zurich, Switzerland \\ E-Mail: tobias.schlegel@erdw.ethz.ch \\ Phone: $(+41446326607)$ \\ Fax: (+4144 632 1827)
}

\begin{abstract}
Determination of absolute trace-element concentrations in fluid inclusions using laserablation (LA) ICPMS requires an internal standard, i.e., the concentration of one element must be independently known from independent observation. Microthermometric determination of the last melting temperature of ice, hydrohalite or halite is routinely used to calculate apparent salinities in wt\% $\mathrm{NaCl}$ equivalent, using phase relations in the binary $\mathrm{H}_{2} \mathrm{O}-\mathrm{NaCl}$ system to estimate $\mathrm{Na}$ concentration. Calculating the concentrations of all other elements requires an empirical correction, if additional salt concentrations are of similar magnitude as that of $\mathrm{NaCl}$. If $\mathrm{CaCl}_{2}$ is the main additional salt component, as in many low-temperature basin and basement brines, absolute $\mathrm{Na}$ concentrations ( $\mathrm{wt} \% \mathrm{NaCl}$ abs.) can be obtained by observing two melting temperatures (hydrohalite and either ice or halite), uniquely defining the major element composition of the fluid in the ternary model system $\mathrm{H}_{2} \mathrm{O}-\mathrm{NaCl}-\mathrm{CaCl}_{2}$ and allowing $\mathrm{Na}$ to be used as internal standard for quantifying all minor and trace elements. Test results for a range of compositions show that calcium concentration can be determined more precisely by microthermometry than by LA-ICPMS analysis, but that both methods agree within error. The combined approach of microthermometry and LA-ICPMS analysis described here permits reliable quantification of major ( $\mathrm{Ca}, \mathrm{Na}$ ) as well as trace element concentrations in sodic-calcic brine inclusions, even in Ca-rich host minerals such as fluorite or Ca-bearing carbonates.
\end{abstract}

Keywords: fluid inclusions; microthermometry; laser ablation ICPMS; calcic brines; quantification, IOCG, internal standard, NaCl equiv., $\mathrm{NaCl}$ abs.

\section{Introduction}

Low-temperature hydrothermal brines commonly contain $\mathrm{CaCl}_{2}$ and $\mathrm{NaCl}$ as dominant salt components, such that fluid inclusions (FI) are approximately described by the ternary $\mathrm{H}_{2} \mathrm{O}$ $\mathrm{NaCl}-\mathrm{CaCl}_{2}$ system (Fritz and Frape, 1982; McKibben et al., 1988). Such calcic-sodic brines occur as fluid inclusions in various mineral deposits such as Mississippi valley-type lead-zinc deposits (Richardson and Pinckney, 1984; Haynes and Kesler, 1987; Shelton et al., 1992; Stoffell et al., 2008), unconformity-related uranium deposits (Wilde et al., 1989; Derome et al., 2005; Shepherd et al., 2005) and in iron-oxide Cu-Au (IOCG)-type deposits (Xu, 2000; Mark et al., 2005; Davidson et al., 2007; Baker et al., 2008; Bertelli and Baker, 2010) including giant Olympic Dam 
in South Australia (Oreskes and Einaudi, 1992). In addition, fluids in various other geologic settings are commonly calcic-sodic, for example sedimentary-basinal brines (Zwart and Touret, 1994; Lowenstein et al., 2003; Schmidt Mumm and Wolfgramm, 2004; Mercadier et al., 2010), groundwater in cratonic basement rocks (Bottomley et al., 1999), sub-seafloor hydrothermal fluids (Vanko et al., 1992), fluids in mafic pegmatoids cutting layered mafic intrusions (Schiffries, 1990), late brines trapped in Archean gold veins (Robert and Kelly, 1987), low temperature hydrothermal Au, Pt, Pd $\pm \mathrm{U}$ mineralization (Mernagh et al., 1994) and porphyry copper deposits (Dilles and Einaudi, 1992; Klemm et al. 2007).

The first-melting temperature (i.e., the eutectic temperature) observed during microthermometry gives an indication of the appropriate fluid system to interpret the composition of natural fluids within fluid inclusions. Vapour-saturated $\mathrm{CaCl}_{2}-\mathrm{NaCl}$-bearing inclusions show distinctive freezing and heating behaviour during low-temperature microthermometry. After undercooling below $-80^{\circ} \mathrm{C}$, the liquid changes instantaneously to a brown-orange mosaic of unidentifiable micro-crystals. Slow heating results in crystal coarsening until first melting can be observed close to the ternary eutectic temperature at $-52{ }^{\circ} \mathrm{C}$ (Yanatieva, 1946). Owing to the difficulty of observing the precise first-melting temperature in fluid inclusions, $\mathrm{NaCl}-\mathrm{CaCl}_{2}$-bearing fluids can be inferred if first melting occurs somewhere between $54^{\circ} \mathrm{C}$ and $-47^{\circ} \mathrm{C}$ (Zwart and Touret, 1994). The melting temperatures of the last and the next-tolast solid phases determine the bulk composition of the fluid (Haynes, 1985; Heinrich et al., 1989; Schiffries, 1990; Vanko et al., 1992; Steele-MacInnis et al., 2011). Complete descriptions of possible melting paths in the $\mathrm{H}_{2} \mathrm{O}-\mathrm{NaCl}-\mathrm{CaCl}_{2}$ system are described elsewhere, including possible difficulties arising from metastability (Schiffries, 1990; Steele-MacInnis et al., 2011). Estimates of bulk fluid composition can be obtained using non-destructive methods like graphically displayed phase equilibrium data obtained from microthermometry (Robert and Kelly, 1987; Vanko et al., 1988; Vanko et al., 1992), or semi-quantitative Raman spectroscopy (Mernagh and Wilde, 1989; Derome et al., 2003, Guillaume et al., 2003).

An overview of thermodynamic and numerical models to estimate compositions in the $\mathrm{H}_{2} \mathrm{O}-\mathrm{NaCl}-\mathrm{CaCl}_{2}$ fluid system is given by Steele-MacInnis et al. (2011) and references therein. LAICPMS is a powerful technique for fast and accurate microanalysis of major and trace-element ratios in individual fluid inclusions, but absolute quantification of concentrations requires an internal standard, i.e., one element with known concentration obtained from an independent measurement or estimation (Günther et al., 1998; Heinrich et al., 2003). The most commonly used internal standard in fluid-inclusion LA-ICPMS analysis is sodium, usually obtained by prior microthermometry. To measure sodium concentration, melting temperatures of ice, hydrohalite $\left(\mathrm{NaCl} \cdot 2 \mathrm{H}_{2} \mathrm{O}\right)$ and/or halite are used to compute apparent salinities of $\mathrm{FI}$, using the known phase equilibria of the binary $\mathrm{H}_{2} \mathrm{O}-\mathrm{NaCl}$ system (Bodnar and Vityk, 1994). For more complex fluids containing salts other than $\mathrm{NaCl}$, an empirical salt correction (Heinrich et al., 1992, 2003) is used to account for additional salts detected by LA-ICPMS, but the accuracy of this correction cannot be tested for each case.

A mathematical description of phase relations in the $\mathrm{H}_{2} \mathrm{O}-\mathrm{NaCl}-\mathrm{CaCl}_{2}$ fluid system has recently been presented by Steele-MacInnis et al. (2011). We have implemented these equations into the SILLS software for LA-ICPMS signal reduction (Guillong et al., 2008), providing the basis to accurately determine trace element concentrations in FI using wt $\% \mathrm{NaCl}$ abs. as a precise internal standard. This paper describes the procedure to obtain wt $\% \mathrm{NaCl}$ abs. in Ca-Na-bearing brines and tests the improved accuracy of trace element concentrations determined by LAICPMS.

\section{Analytical setup and sample description}

We performed careful petrography to select assemblages of multiple coeval Ca-Na bearing fluid inclusions (FIA = group of fluid inclusions with consistent phase proportions entrapped at the same time, e.g., along a single fracture plane or growth zone; Goldstein and 
Reynolds, 1994). Samples originate from the Prominent Hill (PH) iron-oxide $\mathrm{Cu}-\mathrm{Au}$ (IOCG) deposit in South Australia and from the low-grade metamorphic base-metal district of Mt. Isa (MTI) in northern Queensland. The fluid inclusions were hosted in quartz or fluorite. Inclusion petrography and microthermometry were conducted using an Olympus BX60 transmitted light microscope and a Linkham heating-freezing stage. The LA-ICPMS setup described in Günther et al. (1998) and Heinrich et al. (2003) was used to determine trace element ratios, parameters are shown in Table 1.

Table 1. Instrumental parameters of the LA-ICPMS and microthermometry systems used in this study.

\begin{tabular}{|c|c|}
\hline \multicolumn{2}{|l|}{ LA-ICPMS System } \\
\hline Laser type & $\begin{array}{l}\text { ArF excimer laser }(193 \mathrm{~nm}) \text { (Coherent, Germany)with homogenized } \\
\text { beam path }\end{array}$ \\
\hline Laser energy for mineral ablation & $>30 \mathrm{~J} / \mathrm{cm}^{2}$ \\
\hline Laser pulse frequency & $10 \mathrm{~Hz}$ \\
\hline Ablation diameter & variable from 5 to $100 \mu \mathrm{m}$ by adjusting a variable aperture \\
\hline ICPMS system & $\begin{array}{l}\text { Elan } 6100 \text { DRC ICP quadrupole mass } \\
\text { Spectrometer from Perkin Elmer }\end{array}$ \\
\hline Carrier gas & $\mathrm{He}, 1.1 \mathrm{l} / \mathrm{min}$ \\
\hline Auxiliary gas & $\mathrm{H}_{2} 5 \mathrm{ml} / \mathrm{min}$ \\
\hline Dwell time & 10ms except for Ca:20ms \\
\hline External std & NIST610 \\
\hline \multicolumn{2}{|l|}{ Microthermometry System } \\
\hline \multirow{7}{*}{$\begin{array}{l}\text { Heating-freezing stage } \\
\text { controlling units } \\
\text { Optical microscope } \\
\text { Objective } \\
\text { Calibration standard }\end{array}$} & Linkham THMSG 600 heating - freezing stage \\
\hline & Linkham LNP and Cl 94 \\
\hline & Nikon Eclipse E600 Pol \\
\hline & $50 x$ \\
\hline & Syn Flinc $®$ fluid inclusion \\
\hline & $\mathrm{H}_{2} \mathrm{O}\left(0^{\circ}\right.$ and $\left.374.1^{\circ} \mathrm{C}\right)$ \\
\hline & $\mathrm{H}_{2} \mathrm{O}-\mathrm{CO}_{2}\left(-56.6^{\circ} \mathrm{C}\right)$ \\
\hline
\end{tabular}

Five different fluid inclusion types were classified according to phase proportions, number and appearance of daughter crystals, inclusion shape and type of host mineral. All five inclusions types described below contain liquid and vapour at room temperature, although they have distinctly variable volume proportions of vapour, and some also consistently contain halite or other small solid phases. In the terminology used here, fluid inclusion types are abbreviated by their room-temperature phases, with capital letters standing for liquid $(\mathrm{L})$, vapour $\left(\mathrm{V}_{\mathrm{x}}\right.$, the subscript $x$ indicates the volume \% of vapour), halite $(\mathrm{H})$ or other solid phase(s) (S). Four of the five inclusion types are found at Prominent Hill. These include types $L V_{5}, L V_{10} S$ and $L V_{20} S$, which were fluorite-hosted FI in calcite-fluorite-barite \pm chalcopyrite veins. These FIA occasionally occurred as pseudo-secondary trails $\left(\mathrm{LV}_{10} \mathrm{~S}\right)$, but were mostly secondary trails and clusters. $L V_{10} S$ and $L V_{20} S$ were equant and angular in shape and had diameters between 6 and $30 \mu \mathrm{m} . \mathrm{LV}_{5}$ had irregular shape and variable sizes between 8 and $100 \mu \mathrm{m}$. Type $\mathrm{LV}_{5} \mathrm{HS}$ assemblages were from quartz in siderite-quartz-chalcopyrite veins, occurring as primary and pseudo-secondary FIA, with consistent sub-rounded shapes and diameters between 5 to $25 \mu \mathrm{m}$. A LV $\mathrm{LV}_{10}$ inclusion assemblage originated from a large locally vuggy late-metamorphic quartz vein associated with regional alteration of metabasalts in the Mt. Isa district (Heinrich et al., 1995). Inclusions have irregular shapes, were likely pseudo-secondary and between 5 and $45 \mu \mathrm{m}$ in diameter. Using the approach detailed in Steele-MacInnis et al (2011), $\mathrm{CaCl}_{2}$ and $\mathrm{NaCl}$ concentrations were calculated from 45 inclusions in 10 individual FIA, based on melting temperatures of solid phases measured by microthermometry.

Element concentration ratios of $\mathrm{K}, \mathrm{Mn}, \mathrm{Fe}, \mathrm{Cs}, \mathrm{Pb}$ and $\mathrm{Ca}$ with respect to $\mathrm{Na}$ were analysed in 45 individual inclusions using LA-ICPMS. The SILLS software package from the 
University of Leeds and ETH Zürich was used for data reduction (Allan et al., 2005, Guillong et al., 2008), including element spike elimination and time integration of background-subtracted, host-corrected FI signals. Each ablation was monitored continually using a transmitted light microscope and as real-time signal from the mass spectrometer, to determine the part of the signal representing the ablated inclusion, such that the fluid inclusion signal could be isolated for integration. Transient LA-ICPMS signals were inspected for each element and considered significant if integrated intensity was above the limit of detection (LOD) of $3 \sigma_{\text {background }}$ (Longerich et al. 1996) and showed an identifiable peak in the data acquisition window.

\section{Analytical procedure and results}

\subsection{Low temperature microthermometry}

The melting sequence (Fig. 1) and temperatures of ice, hydrohalite and halite hosted in selected FIA in quartz and fluorite from Prominent Hill and quartz from Mt. Isa indicated $\mathrm{Ca}^{2+}$ and $\mathrm{Na}^{+}$as major cations. This was confirmed by the LA-ICPMS data, showing that additional cations (e.g. $\mathrm{K}, \mathrm{Fe}$, etc.) were usually less than one fifth of the Na concentration. Thus, we interpreted the measured melting temperatures using the phase equilibria for $\mathrm{H}_{2} \mathrm{O}-\mathrm{NaCl}-\mathrm{CaCl}_{2}$ assuming that effects of those minor cations on the microthermometric measurements are small. With careful cyclic heating and cooling (Haynes, 1985), individual last melting temperatures of ice, hydrohalite and halite could each be measured reliably, within a typical reproducibility of \pm $0.2^{\circ} \mathrm{C}$ or better. Salinities in the $\mathrm{H}_{2} \mathrm{O}-\mathrm{NaCl}-\mathrm{CaCl}_{2}$ system were calculated from combinations of the temperatures of either final melting of ice and hydrohalite, or melting of ice and final dissolution of halite. These measured values were then used as input parameters in a Microsoft ${ }^{\odot}$ Excelbased calculation sheet, based on the empirical model of Steele-MacInnis et al. (2011). The model uses a set of equations describing the liquidus surface and cotectic melting curves in parts of the $\mathrm{H}_{2} \mathrm{O}-\mathrm{NaCl}-\mathrm{CaCl}_{2}$ phase diagram. Depending on the observed melting phases and their final melting temperature during microthermometry the model uses two phase melting temperatures as input parameters and yields estimates of total salinity as well as independent $\mathrm{CaCl}_{2}$ and $\mathrm{NaCl}$ concentrations within each individual inclusion.

Low-temperature microthermometry of vapour-saturated $\mathrm{CaCl}_{2}-\mathrm{NaCl}$-bearing FI showed a distinctive freezing and heating behaviour (Fig. 1a-e). Upon freezing, the liquid changed instantaneously into an orange-brown microgranular mass (Fig. 1c). Heating resulted in coarsening of still unidentifiable crystals (Fig. 1d). A clearly visible liquid phase was usually observed by heating up to $-48^{\circ} \mathrm{C}$. With further melting, ice crystals became transparent with a clear relief against their host and were therefore easy to recognise (Fig. 1e). Hydrohalite appeared as a greenish and birefringent solid (Fig. 1e). During heating, FI may have either ice, hydrohalite or halite as the last melting (liquidus) phase (Fig. 2a-c). Observed melting paths are described below, where $\mathrm{T}_{\mathrm{m} 1}$ and $\mathrm{T}_{\mathrm{m} 2}$ denote the temperature of the second-to-last and last solid phases to melt, respectively. Whether the second-to-last or last phase to melt is ice, hydrohalite or halite depends on the bulk composition of the fluid. The combination of $\mathrm{T}_{\mathrm{m} 1}$ and $\mathrm{T}_{\mathrm{m} 2}$ can be used to uniquely determine the bulk fluid composition in the $\mathrm{H}_{2} \mathrm{O}-\mathrm{NaCl}-\mathrm{CaCl}_{2}$ system (Fig. 2). In all the FI studied here, the first solid to melt at the ternary eutectic was likely antarcticite (Fig. 2a). Further heating lead to melting of ice and hydrohalite along the ice-hydrohalite cotectic curve. 


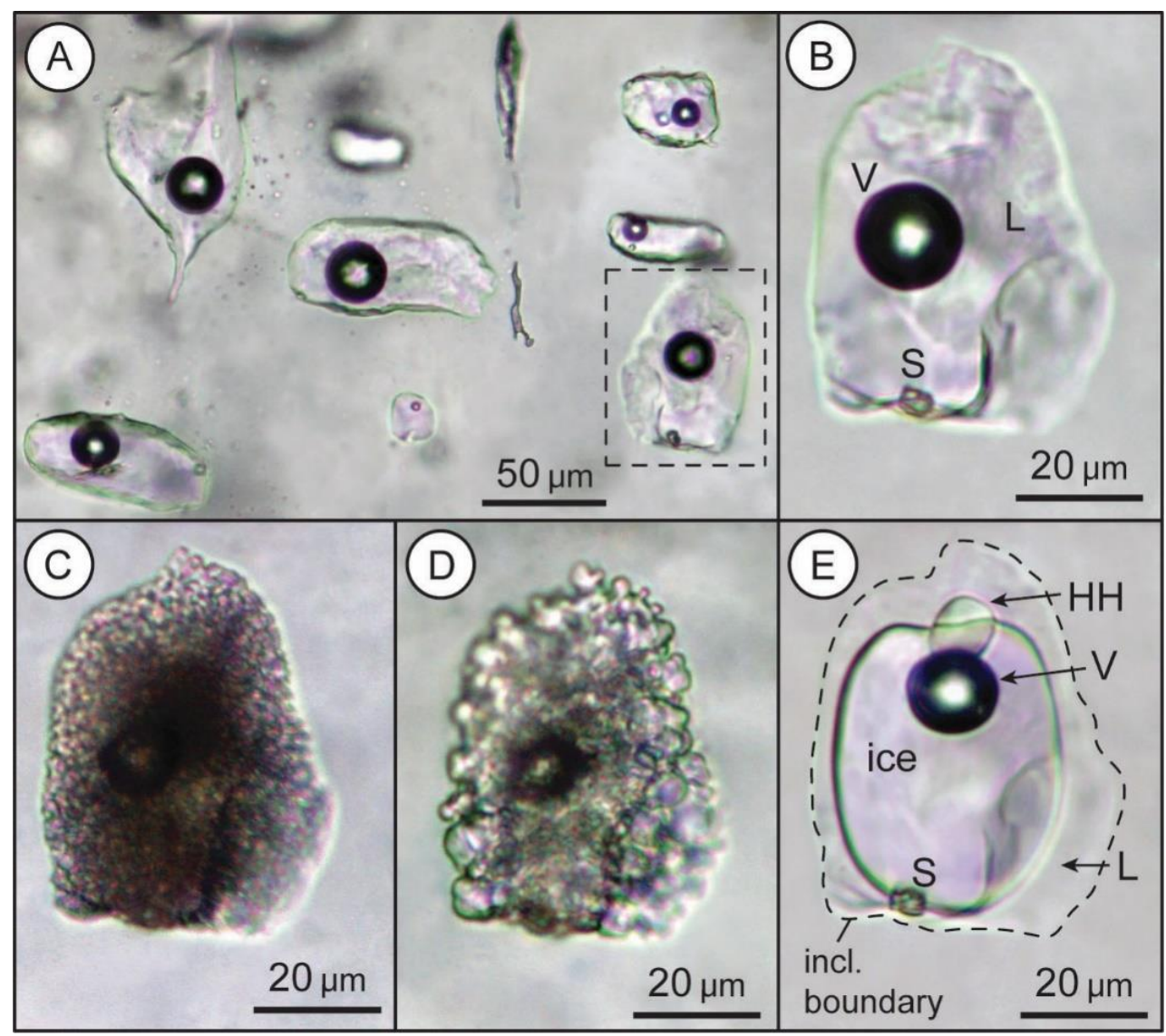

Figure 1. Typical freezing and melting behavior of Ca-Na-dominated fluids (cf. Zwart and Touret, 1994). A: Fluid inclusion assemblage at $25^{\circ} \mathrm{C}$; B: single inclusion at $20^{\circ} \mathrm{C} ; \mathrm{C}:-100^{\circ} \mathrm{C}$, distinct freezing behavior showing brown- orange tint; D: $-44^{\circ} \mathrm{C}$, crystal grain coarsening of ice and hydrohalite after passing the eutectic temperature at $-52^{\circ} \mathrm{C}$; $\mathrm{E}$ : cotectic melting of ice and hydrohalite single crystals at $-29^{\circ} \mathrm{C}$.

a)

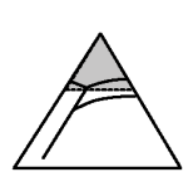

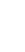

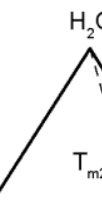

$\mathrm{H}_{2} \mathrm{O}$<smiles>C1CCCC1</smiles>

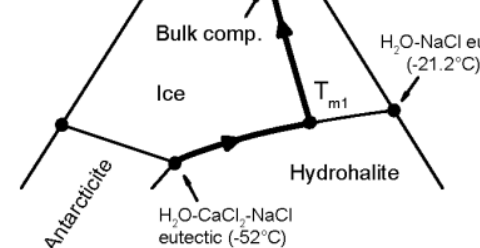

F $\quad \begin{array}{ll}\mathrm{H}_{2} \mathrm{O}-\mathrm{CaCl}{ }_{2}-\mathrm{NaCl} \\ \text { eutectic }\left(-52^{\circ} \mathrm{C}\right)\end{array}$

c)

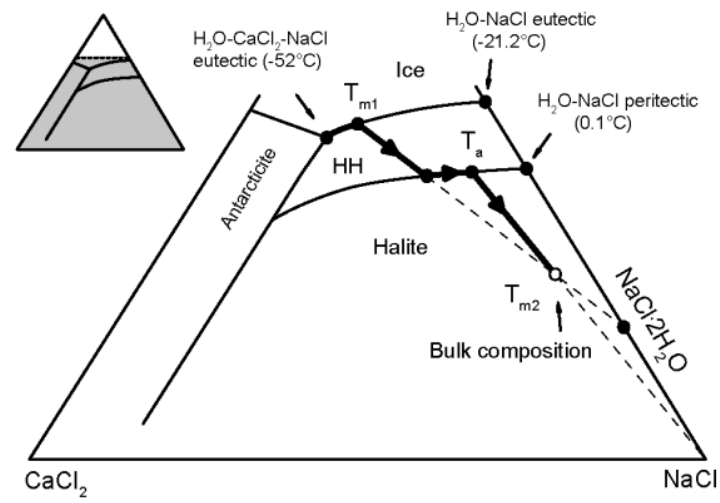

b)
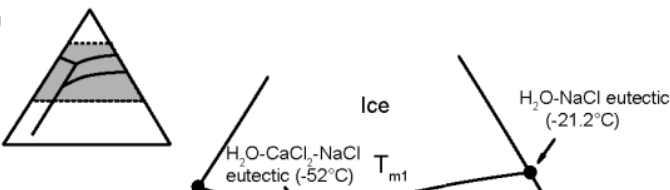

$\mathrm{H}_{2} \mathrm{O}-\mathrm{NaCl}$ peritectic $\left(0.1^{\circ} \mathrm{C}\right)$ Halite

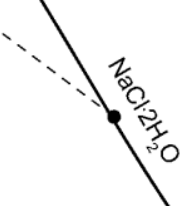

Figure 2. Observed melting paths in the ternary diagram H2O-NaCl-CaCl2 (modified after Steele-MacInnis et al., 2011) for three bulk compositions represented in the test assemblages. See text for discussion. 
Inclusions with bulk composition in the field of the ice liquidus displayed complete cotectic melting of hydrohalite (Fig. $2 \mathrm{a}, \mathrm{T}_{\mathrm{m} 1}$ ). As temperature was increased above $\mathrm{T}_{\mathrm{m} 1}$, the liquid composition evolved toward the $\mathrm{H}_{2} \mathrm{O}$ apex until all ice was molten, defining the bulk fluid composition in the ternary system (Fig. 2a, $\mathrm{T}_{\mathrm{m} 2}$ ). Inclusions of this type required particularly careful measurement because they contained only a small amount of hydrohalite when frozen, such that there was little hydrohalite to melt along the cotectic line. Frozen inclusions of this type were heated until only one small ice crystal remained. By re-cooling down from this temperature, this small "seed" crystal could be grown into a large single crystal of ice. At $-100{ }^{\circ} \mathrm{C}$, the inclusions were completely frozen again showing one large ice crystal filling a large proportion of the inclusion volume. Slow heating toward the eutectic (at a maximum heating rate of $\leq 5{ }^{\circ} \mathrm{C} / \mathrm{min}$ ) prevented formation of the mosaic texture, which limits the visibility of phase transitions. After increasing temperature above the eutectic, heating at a rate of $\leq 0.5$ ${ }^{\circ} \mathrm{C} / \mathrm{min}$ usually led to formation of visible hydrohalite crystals, which gradually merged to measurable crystal sizes. Alternatively, careful heating and cooling around the eutectic led to coalescence of small hydrohalite crystals. In both cases, the final melting temperature of the hydrohalite crystal could then be measured.

For inclusions with bulk compositions in the liquidus field of hydrohalite (Fig. 2b), ice melted before hydrohalite on the cotectic, and therefore $\mathrm{T}_{\mathrm{m} 1}$ represented the melting temperature of ice. Leaving the cotectic line upon further heating, the liquid composition in the inclusion evolved directly towards the composition of hydrohalite until all remaining hydrohalite finally melted (Fig. $2 \mathrm{~b}, \mathrm{~T}_{\mathrm{m} 2}$ ). When ice was consumed before hydrohalite, the subsequent melting of hydrohalite crystals could usually be observed relatively easily. Otherwise, slow heating rates of $\leq 1$ to $2{ }^{\circ} \mathrm{C} / \mathrm{min}$ were used to allow the small remaining hydrohalite crystals to merge. Sometimes accretion of hydrohalite crystals was slow or the final hydrohalite melting temperature occurred close to the ice melting temperature. Both of these phenomena made observation of hydrohalite melting difficult. In those cases, holding the temperature constant just above $\mathrm{T}_{\mathrm{m} 1}$ for a few minutes led to coalescence of the remaining hydrohalite crystals. Hydrohalite melting could then be observed accurately. In practice, hydrohalite can sometimes disappear above the $0.1^{\circ} \mathrm{C}$ peritectic of $\mathrm{NaCl}-\mathrm{H}_{2} \mathrm{O}$, indicating metastable melting behaviour (Zwart and Touret, 1994; Steele-MacInnis et al., 2011). FI showing such metastable melting were not included in this study.

Inclusions with bulk compositions in the halite liquidus field (Fig. 2c) showed a somewhat different evolution. After leaving the eutectic with complete consumption of antarcticite, ice was the next phase to disappear along the ice-hydrohalite cotectic line (Fig. 2c, $\mathrm{T}_{\mathrm{m} 1}$ ). Again the composition evolved straight toward the hydrohalite composition, but in this case intersected the hydrohalite-halite peritectic phase boundary. Hydrohalite was converted into halite during heating while releasing chemically bonded water (Fig. 2c, $\mathrm{T}_{\mathrm{a}}$ ). With further heating, the liquid composition evolved directly towards halite until the last halite crystal dissolved completely during heating runs (Fig. 2c, $\mathrm{T}_{\mathrm{m} 2}$ ). Melting of hydrohalite was sometimes sluggish or delayed due to metastability. Thus, for FI in the halite liquidus field, next-to-last melting (namely hydrohalite melting or peritectic phase-conversion temperatures) was not used for salinity determination. Instead, combinations of the final ice melting with the corresponding final halite dissolution temperature were used to determine fluid bulk composition. This is shown graphically in Figure 2c.

Fluid inclusions used in this study include only those in which at least one phase was clearly identified and its melting temperature was precisely measured by microthermometry. However, it was not always possible to observe both ice melting and its corresponding hydrohalite/halite melting in every individual inclusion within an FIA. For inclusions for which one or the other melting temperature could not be observed, the average melting temperature from successful measurements within the same FIA were used to replace the missing melting temperature. This approach is based on the principle that fluid inclusions within a homogeneously trapped fluid inclusion assemblage should have the same composition and the 
same microthermometric behaviour, provided that they were trapped as a single homogeneous phase and were not modified by post-entrapment processes. Applying this procedure to our dataset is justified because the FIA have consistent phase ratios and the microthermometric measurements within each FIA were generally very consistent (mostly within less than $\pm 1^{\circ} \mathrm{C}$; in two cases up to $\pm 3{ }^{\circ} \mathrm{C}$, and only in one case up to $\pm 6^{\circ} \mathrm{C}$ for ice and hydrohalite; up to $\pm 9^{\circ} \mathrm{C}$ for halite; Table 2). Using this procedure, the composition of each FI was computed individually, allowing an estimate of overall analytical uncertainty for each fluid sample represented by an inclusion assemblage.

Table 2. Microthermometric data and $\mathrm{CaCl} 2 \mathrm{-NaCl}$ salinity from selected fluid inclusions from Prominent Hill (PHsample no. 15.2, 82 and 98.2) and Mount Isa (MTI sample-no. 73529 in used in Heinrich et al., 1995). Salinity calculated based on combined final ice and hydrohalite melting or ice melting and final halite dissolution temperatures using the model of Steele-MacInnis et al. (2011). Data exclude measurements of metastable hydrohalite melting. The number in the parentheses is the number of measured inclusions for the average.

\begin{tabular}{|c|c|c|c|c|c|c|c|c|c|c|c|c|}
\hline Sample & FIA / \# & $\mu \mathrm{m}$ & $\begin{array}{l}\text { first melt } \\
-52 \text { to - }\end{array}$ & $\operatorname{Tm}($ ice $)$ & $\operatorname{Tm}(\mathrm{HH})$ & $\operatorname{Tm}(\mathrm{H})$ & wt $\%$ & wt $\%$ & wt $\%$ & wt $\%$ & wt $\%$ & $\mathrm{Ca} /(\mathrm{Ca}+\mathrm{N}$ \\
\hline \multirow{5}{*}{$\begin{array}{l}\text { PH98.2_ } \\
\text { LV10S }\end{array}$} & FIA & & & $-26.4 \pm 1.7$ & $-5.7 \pm 0.6(7)$ & & & & & & & \\
\hline & 2 & 22 & $\mathrm{x}$ & -25.9 & -6.6 & & 15.3 & 11.6 & 16.7 & 6.0 & 4.2 & 0.41 \\
\hline & 4 & 18 & $\mathrm{x}$ & -26.0 & -5.4 & & 15.2 & 11.7 & 16.7 & 6.0 & 4.2 & 0.41 \\
\hline & 7 & 14 & $\mathrm{x}$ & -26.0 & -6.3 & & 15.2 & 11.7 & 16.7 & 6.0 & 4.2 & 0.41 \\
\hline & 12 & 12 & $\mathrm{x}$ & $-26.4^{a}$ & -5.8 & & 14.6 & 12.4 & 16.8 & 5.7 & 4.5 & 0.44 \\
\hline \multirow{3}{*}{$\begin{array}{l}\text { PH98.2_ } \\
\text { LV5_1 }\end{array}$} & FIA & & & $-6.4 \pm 0.8(4)$ & $-24.0 \pm 0.1$ & & & & & & & \\
\hline & 1 & 24 & $\mathrm{x}$ & -6.0 & -23.9 & & 6.4 & 3.1 & 5.9 & 2.5 & 1.1 & 0.31 \\
\hline & 2 & 100 & $\mathrm{x}$ & -6.5 & -24.0 & & 6.8 & 3.4 & 6.3 & 2.7 & 1.2 & 0.31 \\
\hline \multirow{3}{*}{$\begin{array}{l}\text { PH98.2_- } \\
\text { LV5_3 }\end{array}$} & FIA & & & $-6.1 \pm 0.8(6)$ & $-25.0 \pm 0.0$ & & & & & & & \\
\hline & 2 & 80 & $\mathrm{x}$ & -5.6 & $-25.0^{\mathrm{a}}$ & & 5.3 & 3.8 & 5.6 & 2.1 & 1.4 & 0.40 \\
\hline & 5 & 80 & $\mathrm{x}$ & $-6.1^{\mathrm{a}}$ & -25.0 & & 5.6 & 4.1 & 6.0 & 2.2 & 1.5 & 0.40 \\
\hline \multirow{6}{*}{$\begin{array}{l}\text { PH82_ } \\
\text { LV20S_1 }\end{array}$} & FIA & & & $-30.6 \pm 1.2$ & $-17.4 \pm 5.4$ & & & & & & & \\
\hline & 1 & 28 & $\mathrm{x}$ & -29.3 & -22.0 & & 9.4 & 17.2 & 16.7 & 3.7 & 6.2 & 0.63 \\
\hline & 3 & 28 & $\mathrm{x}$ & -31.5 & $-17.4^{a}$ & & 8.2 & 19.4 & 17.4 & 3.2 & 7.0 & 0.68 \\
\hline & 5 & 34 & $\mathrm{x}$ & -28.5 & -25.6 & & 9.7 & 16.3 & 16.3 & 3.8 & 5.9 & 0.61 \\
\hline & 15 & 19 & $\mathrm{x}$ & -30.0 & $-17.4^{a}$ & & 9.4 & 17.8 & 17.0 & 3.7 & 6.4 & 0.64 \\
\hline & 17 & 14 & $\mathrm{x}$ & -30.9 & $-17.4^{a}$ & & 8.6 & 18.8 & 17.2 & 3.4 & 6.8 & 0.67 \\
\hline \multirow{7}{*}{$\begin{array}{l}\text { PH15.2 } \\
\text { LV5HS_1 }\end{array}$} & FIA & & & $-27.4 \pm 0.6$ & $16.1 \pm 2.9(3)$ & $258.7 \pm 8.6$ & & & & & & \\
\hline & 1 & 20 & $\mathrm{x}$ & -27.5 & 16.3 & 267.5 & 27.8 & 9.9 & 23.2 & 11.0 & 3.6 & 0.25 \\
\hline & 2 & 13 & $\mathrm{x}$ & -27.7 & 18.8 & $258.7^{a}$ & 26.9 & 10.3 & 22.9 & 10.6 & 3.7 & 0.26 \\
\hline & 3 & 12 & $\mathrm{x}$ & $-27.4^{a}$ & & 254.2 & 26.6 & 10.2 & 22.6 & 10.5 & 3.7 & 0.26 \\
\hline & 4 & 24 & $\mathrm{x}$ & -27.4 & & $258.7^{a}$ & 27.0 & 10.0 & 22.8 & 10.6 & 3.6 & 0.25 \\
\hline & 5 & 8 & $\mathrm{x}$ & $-27.4^{a}$ & & 263.2 & 27.5 & 9.9 & 23.0 & 10.8 & 3.6 & 0.25 \\
\hline & 6 & 20 & $\mathrm{x}$ & -26.4 & 13.1 & 246.0 & 26.5 & 9.3 & 22.0 & 10.4 & 3.4 & 0.24 \\
\hline \multirow{8}{*}{$\begin{array}{l}\text { PH15.2_ } \\
\text { LV5HS_2 }\end{array}$} & FIA & & & $-27.4 \pm 0.0$ & $14.7 \pm 0.3(2)$ & $260.6 \pm 4.6$ & & & & & & \\
\hline & 2 & 22 & $\mathrm{x}$ & $-27.4^{a}$ & 14.5 & 268.2 & 28.0 & 9.8 & 23.2 & 11.0 & 3.5 & 0.24 \\
\hline & 3 & 20 & $\mathrm{x}$ & -27.4 & & 254.1 & 26.6 & 10.2 & 22.6 & 10.5 & 3.7 & 0.26 \\
\hline & 6 & 12 & $\mathrm{x}$ & -27.4 & & $260.6^{a}$ & 27.2 & 10.0 & 22.9 & 10.7 & 3.6 & 0.25 \\
\hline & 8 & 10 & $\mathrm{x}$ & $-27.4^{a}$ & & 259.4 & 27.1 & 10.0 & 22.8 & 10.7 & 3.6 & 0.25 \\
\hline & 9 & 11 & $\mathrm{x}$ & $-27.4^{a}$ & & 261.2 & 27.3 & 10.0 & 22.9 & 10.7 & 3.6 & 0.25 \\
\hline & 10 & 10 & $\mathrm{x}$ & $-27.4^{a}$ & & 261.9 & 27.3 & 10.0 & 23.0 & 10.8 & 3.6 & 0.25 \\
\hline & 11 & 8 & $\mathrm{x}$ & $-27.4^{a}$ & & 258.6 & 27.0 & 10.1 & 22.8 & 10.6 & 3.6 & 0.25 \\
\hline \multirow{5}{*}{$\begin{array}{l}\text { PH15.2_ } \\
\text { LV5HS_4 }\end{array}$} & FIA & & & $-32.2 \pm 1.9$ & & $267.1 \pm 4.6$ & & & & & & \\
\hline & 1 & 22 & $\mathrm{x}$ & -34.4 & & $267.1^{\mathrm{a}}$ & 25.6 & 14.3 & 24.7 & 10.1 & 5.2 & 0.34 \\
\hline & 2 & 14 & $\mathrm{x}$ & -31.1 & & 263.7 & 26.0 & 12.7 & 23.9 & 10.2 & 4.6 & 0.31 \\
\hline & 3 & 12 & $\mathrm{x}$ & -31.1 & & 272.4 & 26.9 & 12.4 & 24.3 & 10.6 & 4.5 & 0.30 \\
\hline & 5 & 10 & $\mathrm{x}$ & $-32.2^{\mathrm{a}}$ & & 265.3 & 25.9 & 13.3 & 24.2 & 10.2 & 4.8 & 0.32 \\
\hline \multirow{5}{*}{$\begin{array}{l}\text { MTI_ } \\
\text { LV10_2 }\end{array}$} & FIA & & & $-23.6 \pm 1.0$ & $-11.0 \pm 1.2$ & & & & & & & \\
\hline & 1 & 44 & $\mathrm{x}$ & -23.2 & -9.2 & & 20.1 & 5.8 & 15.9 & 7.9 & 2.1 & 0.21 \\
\hline & 3 & 24 & $\mathrm{x}$ & -23.2 & -11.1 & & 19.8 & 5.8 & 15.8 & 7.8 & 2.1 & 0.21 \\
\hline & 8 & 12 & $\mathrm{x}$ & -23.3 & -11.9 & & 19.5 & 6.1 & 15.7 & 7.7 & 2.2 & 0.22 \\
\hline & 9 & 10 & $\mathrm{x}$ & -23.6 & $-11.0^{a}$ & & 19.0 & 6.8 & 15.9 & 7.5 & 2.5 & 0.25 \\
\hline \multirow{7}{*}{$\begin{array}{l}\text { MT1_ } \\
\text { LV10_4 }\end{array}$} & FIA & & & $-23.0 \pm 0.4$ & $-23.2 \pm 0.2$ & & & & & & & \\
\hline & 1 & 35 & $\mathrm{x}$ & -23.1 & -23.2 & & 17.9 & 6.1 & 14.7 & 7.0 & 2.2 & 0.24 \\
\hline & 3 & 30 & $\mathrm{x}$ & -23.2 & -22.7 & & 18.0 & 6.1 & 14.8 & 7.1 & 2.2 & 0.24 \\
\hline & 4 & 27 & $\mathrm{x}$ & -23.4 & -23.4 & & 17.5 & 6.6 & 14.8 & 6.9 & 2.4 & 0.26 \\
\hline & 5 & 12 & $\mathrm{x}$ & -22.4 & -23.2 & & 17.5 & 6.0 & 14.5 & 6.9 & 2.2 & 0.24 \\
\hline & 6 & 7 & $\mathrm{x}$ & -22.4 & -23.2 & & 17.5 & 6.0 & 14.5 & 6.9 & 2.2 & 0.24 \\
\hline & 7 & 10 & $\mathrm{x}$ & -23.1 & -23.2 & & 17.9 & 6.1 & 14.7 & 7.0 & 2.2 & 0.24 \\
\hline
\end{tabular}


Table 2. (continued)

\begin{tabular}{|c|c|c|c|c|c|c|c|c|c|c|c|c|}
\hline Sample & FIA / \# & $\mu \mathrm{m}$ & $\begin{array}{l}\text { first melt } \\
-52 \text { to - }\end{array}$ & $\operatorname{Tm}(i c e)$ & $\operatorname{Tm}(\mathrm{HH})$ & $\operatorname{Tm}(\mathrm{H})$ & wt $\%$ & wt $\%$ & wt $\%$ & wt $\%$ & wt $\%$ & $\mathrm{Ca} /(\mathrm{Ca}+\mathrm{N}$ \\
\hline MTI_ & FIA & & & $-23.5 \pm 0.3$ & $-12.4 \pm 0.2$ & & & & & & & \\
\hline \multirow[t]{5}{*}{ LV10_6 } & 2 & 22 & $\mathrm{x}$ & -24.1 & -12.3 & & 17.8 & 8.1 & 15.9 & 7.0 & 2.9 & 0.29 \\
\hline & 4 & 18 & $\mathrm{x}$ & -23.5 & -12.3 & & 19.0 & 6.6 & 15.8 & 7.5 & 2.4 & 0.24 \\
\hline & 5 & 26 & $\mathrm{x}$ & -23.2 & -12.5 & & 19.7 & 5.9 & 15.7 & 7.7 & 2.1 & 0.22 \\
\hline & 6 & 20 & $\mathrm{x}$ & -23.4 & -12.3 & & 19.2 & 6.4 & 15.7 & 7.6 & 2.3 & 0.23 \\
\hline & 9 & 12 & $\mathrm{x}$ & -23.4 & $-12.4^{a}$ & & 19.2 & 6.4 & 15.7 & 7.6 & 2.3 & 0.23 \\
\hline
\end{tabular}

a FI showed either metastable melting of one phase, or final melting was not observed. In both cases the FIA average temperature of the respective phase was used to calculate the individual FI salinity.

\subsection{Composition in the $\mathrm{H}_{2} \mathrm{O}-\mathrm{NaCl}-\mathrm{CaCl}_{2}$ ternary system}

Results were calculated in terms of weight concentrations of $\mathrm{NaCl}, \mathrm{CaCl}_{2}$, total salinity (chloride equivalent, $\mathrm{S}_{\mathrm{Cr}}$ ), absolute $\mathrm{Na}^{+}$and $\mathrm{Ca}^{2+}$ concentrations and $\mathrm{Ca} /(\mathrm{Na}+\mathrm{Ca}$ ) proportions (Table 2). Calculated salinities exclude any data obtained from metastable melting behaviour. In general, fluid inclusions used in this study showed a range of assemblage-averaged $\mathrm{Ca} /(\mathrm{Ca}+\mathrm{Na})$ from $0.22 \pm 0.02$ to $0.63 \pm 0.03$ (Table 2, Fig. 3).
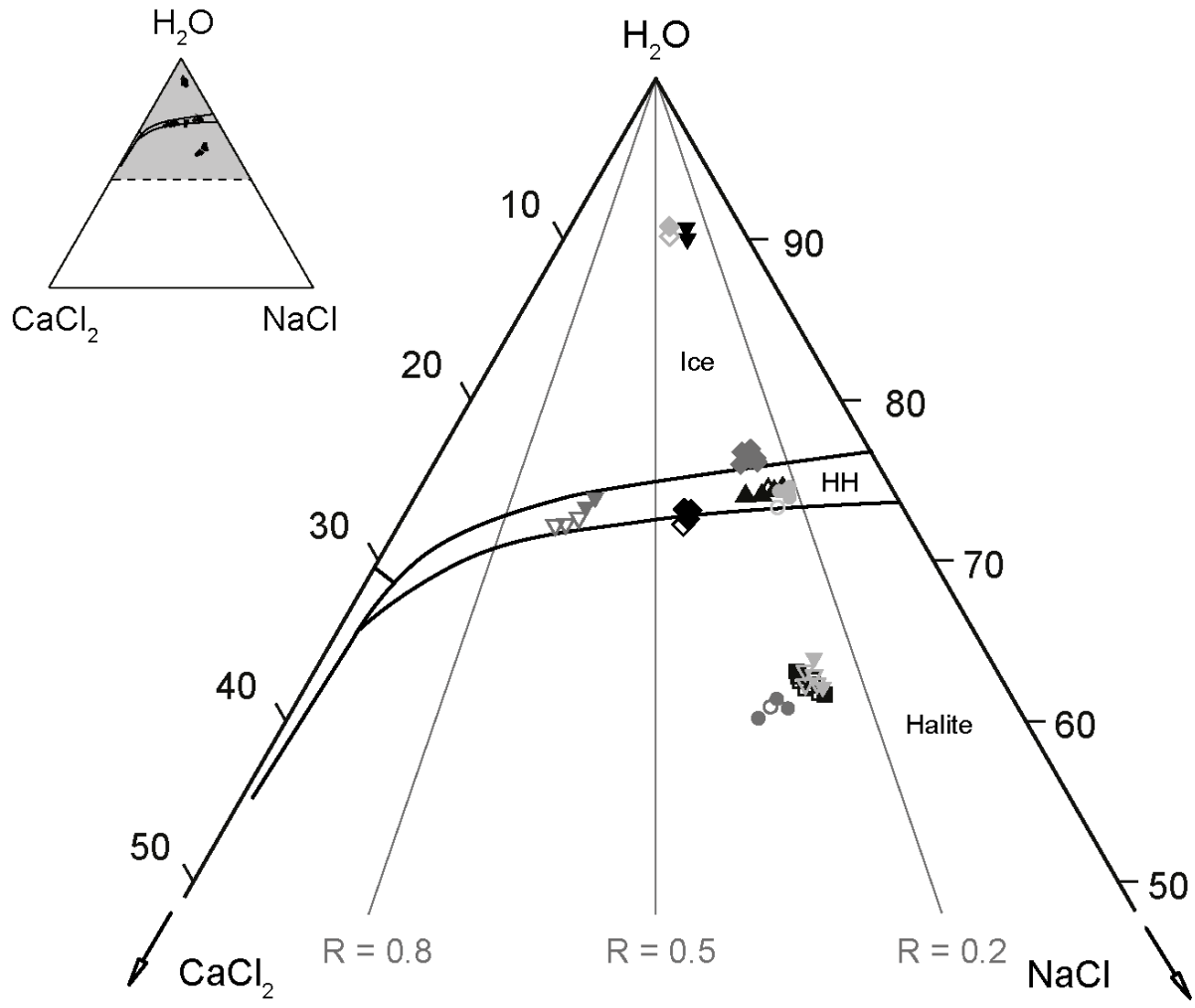

Prominent Hill

Mount Isa

- PH15.2_LV5HS_2

PH15.2_LV5HS_4

$\nabla$ PH98.2_LV5_1

Figure 3. Ternary diagram showing $\mathrm{H} 2 \mathrm{O}-\mathrm{NaCl}-\mathrm{CaCl} 2$ fluid composition of selected fluid inclusion from Prominent Hill and Mount Isa based on microthermometry. Open symbols indicate FI within an assemblage where microthermometry measurements required the use of an average value for the final melting temperature of one of the phases, based on other inclusions in the same assemblage (either ice, hydrohalite or halite).

\subsection{Major and trace element composition determined by LA-ICPMS}


Combined results from microthermometry and LA-ICPMS analysis are reported in Table 3 and in Figure 4, showing individual FI compositions, including LOD for elements determined by LA-ICPMS. LA-ICPMS data showing element concentrations below the LOD were marked as "< LOD". The inclusions are sorted by decreasing sodium content within each FIA. In general, all inclusion types contained major amounts of $\mathrm{Na}$ and $\mathrm{Ca}$ and lesser amounts of $\mathrm{K}$ and $\mathrm{Fe}, \mathrm{Mn}, \mathrm{Pb}$ and Cs. LA-ICPMS data thus confirm the assumption that $\mathrm{Na}$ and $\mathrm{Ca}$ are the dominant cations. Only the $\mathrm{K}$ concentrations in a few individual FI within some FIA approach the measured $\mathrm{Ca}$ contents (e.g. PH15.2_LV5H_2 inclusion 1 and 2, MTI_LV10_2 inclusion 3 and MTI_LV10_4 inclusion 6) (Table 2) but this is at least partly explained by the large scatter in the Ca and $\mathrm{K}$ peak intensities. Owing to lack of experimental data, no attempt was made to correct for the influence of minor salts on phase relations in the ternary $\mathrm{H}_{2} \mathrm{O}-\mathrm{NaCl}-\mathrm{CaCl}_{2}$ fluid system.

Table 3. Fluid inclusion major and trace element composition determined with LA-ICPMS and microthermometry for selected assemblages from Prominent Hill (PH-sample no 15.2,82 and 98.2) and Mount Isa (MTI sample-no. 73529 in used in Heinrich et al., 1995). Abbreviations: n.i. = not included due to insufficient signal detection (SILLS quantification resulting in concentration above the $3 \sigma$ value but without a visible peak justifying the element quantification); MT = results from microthermometry; LA = results from laser ablation ICPMS; LOD = limit of detection)

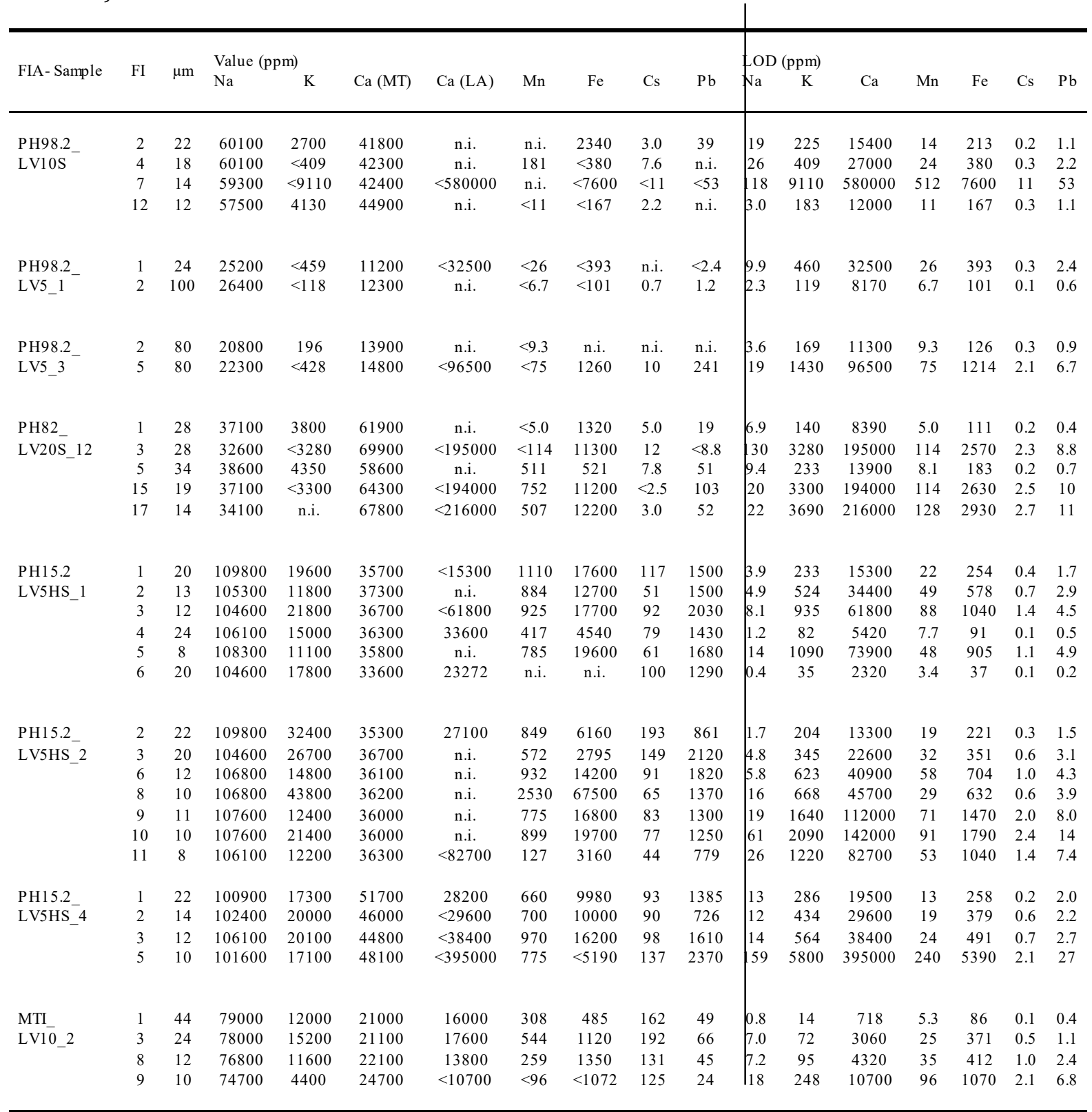

Table 3. (continued) 


\begin{tabular}{|c|c|c|c|c|c|c|c|c|c|c|c|c|c|c|c|c|c|}
\hline \multirow{2}{*}{ FIA-Sample } & \multirow{2}{*}{ FI } & \multirow{2}{*}{$\mu \mathrm{m}$} & \multicolumn{8}{|c|}{ Value (ppm) } & \multicolumn{7}{|c|}{ LOD (ppm) } \\
\hline & & & $\mathrm{Na}$ & K & $\mathrm{Ca}(\mathrm{MT})$ & $\mathrm{Ca}(\mathrm{LA})$ & $\mathrm{Mn}$ & $\mathrm{Fe}$ & Cs & $\mathrm{Pb}$ & $\mathrm{Na}$ & K & $\mathrm{Ca}$ & $\mathrm{Mn}$ & $\mathrm{Fe}$ & $\mathrm{Cs}$ & $\mathrm{Pb}$ \\
\hline \multirow{6}{*}{$\begin{array}{l}\mathrm{MTI}_{-} \\
\mathrm{LV} 10_{-} 4\end{array}$} & 1 & 35 & 70400 & 13300 & 22000 & 21200 & 266 & 384 & 174 & 24 & 3.1 & 39 & 1640 & 14 & 179 & 0.3 & 0.9 \\
\hline & 3 & 30 & 70900 & 13000 & 22000 & 20900 & $<147$ & 4080 & 86 & 200 & 40 & 388 & 16100 & 147 & 1960 & 3.4 & 13 \\
\hline & 4 & 27 & 68800 & 14300 & 24000 & 38400 & 287 & $<848$ & 174 & 53 & 19 & 175 & 7500 & 63 & 848 & 0.9 & 3.5 \\
\hline & 5 & 12 & 69000 & 9600 & 21600 & 18600 & n.i & $<1880$ & 131 & 16 & 31 & 480 & 20300 & 177 & 2500 & 5.0 & 12 \\
\hline & 6 & 7 & 69000 & 20200 & 21600 & 22700 & $<102$ & $<1379$ & 110 & 22 & 21 & 277 & 11700 & 102 & 1379 & 2.5 & 6.4 \\
\hline & 7 & 10 & 70400 & 11500 & 22000 & 28900 & 354 & 4440 & 141 & 22 & 14 & 193 & 8270 & 76 & 1044 & 1.9 & 4.8 \\
\hline \multirow{5}{*}{$\begin{array}{l}\text { MTI_- } \\
\text { LV10_6 }\end{array}$} & 2 & 22 & 70000 & 10200 & 29100 & 50400 & $<285$ & $<3250$ & n.i. & $<16$ & 57 & 747 & 31400 & 285 & 3250 & 9.5 & 16 \\
\hline & 4 & 18 & 74900 & 11600 & 23900 & $<20800$ & 228 & 2530 & 126 & 13 & 37 & 470 & 20800 & 175 & 1640 & 4.3 & 10 \\
\hline & 5 & 26 & 77300 & 10000 & 21200 & 11400 & 195 & $<605$ & 135 & $<3.3$ & 8.5 & 110 & 4970 & 42 & 605 & 1.2 & 3.3 \\
\hline & 6 & 20 & 75700 & 13500 & 23000 & 39900 & n.i. & $<774$ & n.i. & n.i. & 10 & 153 & 6480 & 58 & 774 & 2.0 & 1.6 \\
\hline & 9 & 12 & 75700 & 8840 & 23000 & $<31900$ & $<278$ & $<3330$ & 37 & 38 & 56 & 732 & 31900 & 278 & 3330 & 6.4 & 12 \\
\hline
\end{tabular}

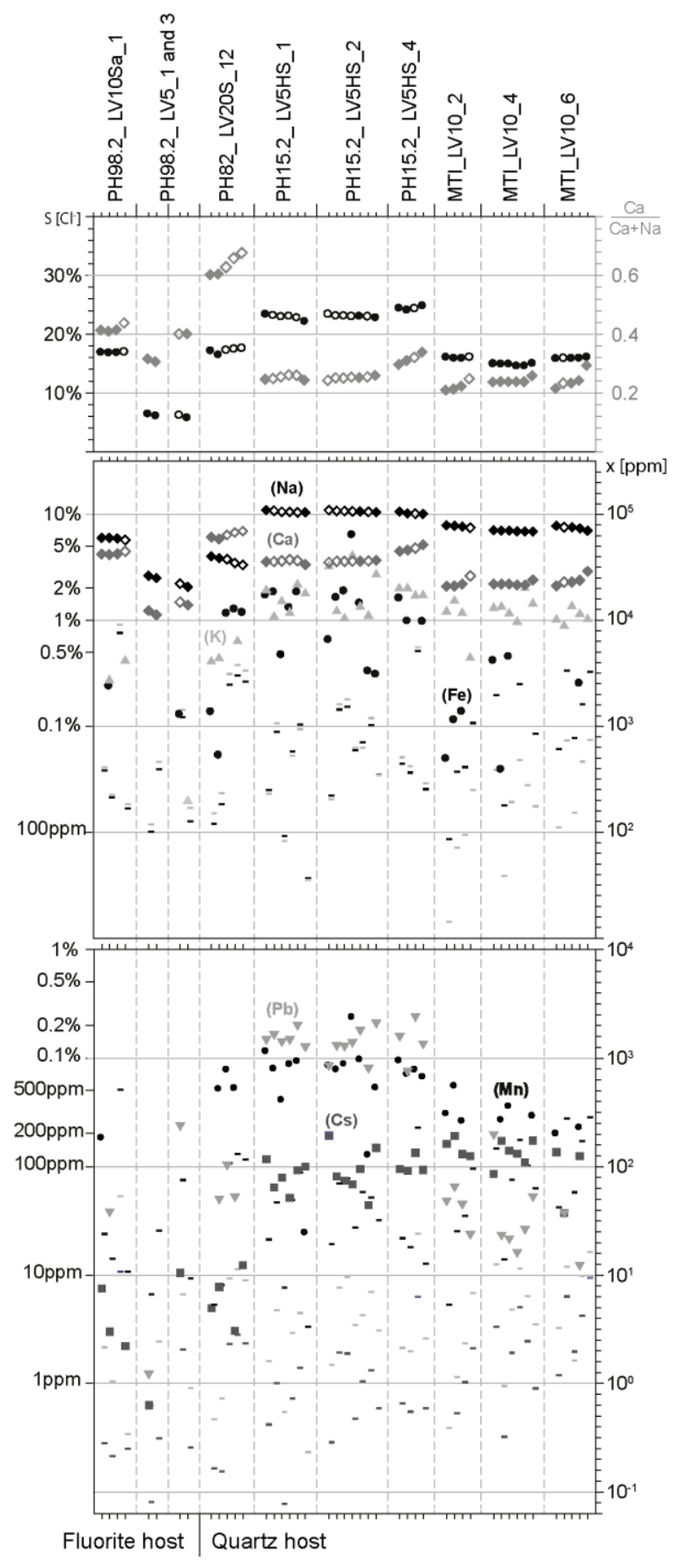

Figure 4. Major and trace element concentrations of FI from Prominent Hill and Mount Isa samples. Dashed lines separate petrographic assemblages. Open symbols of $\mathrm{Na}, \mathrm{Ca}$ and total salinity $\mathrm{S}[\mathrm{Cl}-]$ indicate microthermometry derived salinities where one average phase melting temperature of the FIA (either ice, hydrohalite or halite) during microthermometry has been used to determine the inclusions salinity. Note the more precise determination of Ca by microthermometry. Other elements $(\mathrm{K}, \mathrm{Fe} \mathrm{Mn}, \mathrm{Pb}$ and Cs) were quantified from LA-ICPMS signals in SILLS software using $\mathrm{wt} \% \mathrm{NaCl}$ abs. as internal standard, confirming that these elements are present in lesser concentrations justifying use of the ternary model system for internal standardisation. Horizontal stripes mark limits of detection for each element in the LA-ICPMS analysis

The greatest source of potential error in this procedure lies in any misinterpretation of the phase types (confusion of ice and 
hydrohalite) during microthermometry. This would lead to dramatically incorrect salinities and element concentrations determined by LA-ICPMS, as illustrated by the following examples. If during microthermometry in FIA PH98.2_LV $\mathrm{LV}_{10} \mathrm{~S}$ (Table 2 and 4) the final melting temperature were erroneously assigned to ice melting instead of assigning it correctly to hydrohalite melting, the calculated salinity in $\mathrm{NaCl}$ eq. (Bodnar and Vityk, 1994) of would be underestimated by $\sim 40 \%$ and therefore lead to significantly lower element concentrations determined by LAICPMS (Table 4). In contrast, observing only final ice melting in FIA PH98.2_LV s_ $_{-}$, the corresponding $\mathrm{NaCl}$ eq. would be more than $40 \%$ higher than $\mathrm{NaCl}$ abs. (Table 4) resulting in overestimation of trace elements during LA-ICPMS analysis. Lesser but still systematic errors result from measuring halite dissolution without observation of hydrohalite melting, e.g. in FIA PH15.2_LV 5 HS_2, using only $\mathrm{NaCl}$ eq. concentration derived from the observed halite dissolution temperature of $\sim 260{ }^{\circ} \mathrm{C}$ leads to $\mathrm{NaCl}$ eq. of $35 \% \mathrm{wt}$, compared to $\mathrm{NaCl}$ abs. of $\sim 27 \%$ wt. Neglecting the effect of Ca during microthermometry incorrectly increases the concentrations of all trace elements determined by LA-ICPMS by $\sim 30 \%$ (Table 4 ) in this FIA. If in FIA PH15.2_LV LV $_{5} \mathrm{HS} 2 \mathrm{NaCl}$ eq. is used as internal standard in combination with the empirical salt correction (Heinrich et al. 1992, 2003) for $\mathrm{K}$ with $\mathrm{K} / \mathrm{Na}>0.1$ and the effect of Ca is neglected because of the difficulties of low count rates and high backgrounds on $\mathrm{Ca}$, the error is overall smaller but elements are still overestimated $\sim 20 \%$ compared to $\mathrm{NaCl}$ abs. internal standardisation (Table 5). Thus, identification of the applicable fluid system and careful microthermometry of two phase transitions can avoid this systematic error and lead to more reliable element concentrations determined by LA-ICPMS.

Table 4. Examples illustrating differences of calculated internal standards for LA-ICPMS element quantification using salinity data ( $\mathrm{NaCl}$ abs.) obtained from observation of two phase melting in the $\mathrm{H} 2 \mathrm{O}-\mathrm{NaCl}-\mathrm{CaCl} 2$ system and internal standard obtained from misinterpreted microthermometric phase melting temperatures using $\mathrm{NaCl}-\mathrm{H} 2 \mathrm{O}$ fluid system (see text for details). The number in the parentheses is the number of measured inclusions for the average.

\begin{tabular}{|c|c|c|c|c|c|c|c|c|c|}
\hline Sample & FIA / & $\mu \mathrm{m}$ & $\operatorname{Tm}($ ice $)$ & $\operatorname{Tm}(\mathrm{HH})$ & $\operatorname{Tm}(H)$ & $\begin{array}{l}\text { wt } \% \mathrm{NaCl} \\
\text { Steele-MacInnis }\end{array}$ & $\begin{array}{r}\text { wt } \% \mathrm{CaCl}_{2} \\
\text { et al. }(2011)\end{array}$ & $\begin{array}{c}\mathrm{wt} \% \mathrm{NaCl} \text { eq. } \\
\text { Bodnar }+ \text { Vityk }\end{array}$ & $\begin{array}{r}\text { Difference of } \mathrm{NaCl} \\
\text { from } \mathrm{NaCl} \text { abs. in \% }\end{array}$ \\
\hline PH98.2_ & FIA & & $-26.4 \pm 1.7$ & $-5.7 \pm 0.7(6)$ & & & & & \\
\hline \multirow[t]{4}{*}{ LV10S } & 2 & 22 & -25.9 & -6.6 & & 15.3 & 11.6 & 10.0 & -34.5 \\
\hline & 4 & 18 & -26.0 & -5.4 & & 15.2 & 11.7 & 8.4 & -45.0 \\
\hline & 7 & 14 & -26.0 & -6.3 & & 15.2 & 11.7 & 9.6 & -36.4 \\
\hline & 12 & 12 & $-26.4^{a}$ & -5.8 & & 14.6 & 12.4 & 9.0 & -38.4 \\
\hline PH98.2_ & FIA & & $-6.4 \pm 0.8(4)$ & $-24.0 \pm 0.1$ & & & & & \\
\hline \multirow[t]{2}{*}{ LV5_1 } & 1 & 24 & -6.0 & -23.9 & & 6.4 & 3.1 & 9.2 & +42.8 \\
\hline & 2 & 10 & -6.5 & -24.0 & & 6.8 & 3.4 & 9.9 & +45.5 \\
\hline PH15.2_ & FIA & & $-27.4 \pm 0.0$ & $14.7 \pm 0.3$ & $260.6 \pm 4.6$ & & & & \\
\hline \multirow[t]{7}{*}{$\mathrm{LV} \mathrm{HS}_{-}^{-}$} & 2 & 22 & $-27.4^{\mathrm{a}}$ & 14.5 & 268.2 & 28.0 & 9.8 & 35.9 & +28.4 \\
\hline & 3 & 20 & -27.4 & & 254.1 & 26.6 & 10.2 & 34.9 & +31.2 \\
\hline & 6 & 12 & -27.4 & & $260.6^{\mathrm{a}}$ & 27.2 & 10.0 & 35.3 & +29.7 \\
\hline & 8 & 10 & $-27.4^{\mathrm{a}}$ & & 259.4 & 27.1 & 10.0 & 35.3 & +30.3 \\
\hline & 9 & 11 & $-27.4^{\mathrm{a}}$ & & 261.2 & 27.3 & 10.0 & 35.4 & +29.7 \\
\hline & 10 & 10 & $-27.4^{\mathrm{a}}$ & & 261.9 & 27.3 & 10.0 & 35.5 & +29.9 \\
\hline & 11 & 8 & $-27.4^{\mathrm{a}}$ & & 258.6 & 27.0 & 10.1 & 35.2 & +30.3 \\
\hline
\end{tabular}

Table 5. Comparison between LA-ICPMS element quantification using $\mathrm{NaCl}$ abs. obtained from observation of two phase melting during microthermometry (left) and element quantification based on $\mathrm{NaCl}$ eq. determined from last halite melting combined with additional salt correction for K/Na > 0.1 (Heinrich et al. 1992, 2003) (right). (abbr.: n.i. = 
not included due to insufficient signal detection (SILLS quantification resulting in concentration above the $3 \sigma$ value but without a visible peak justifying the element quantification); MT = results from microthermometry; LA = results from laser ablation ICPMS; LOD = limit of detection).

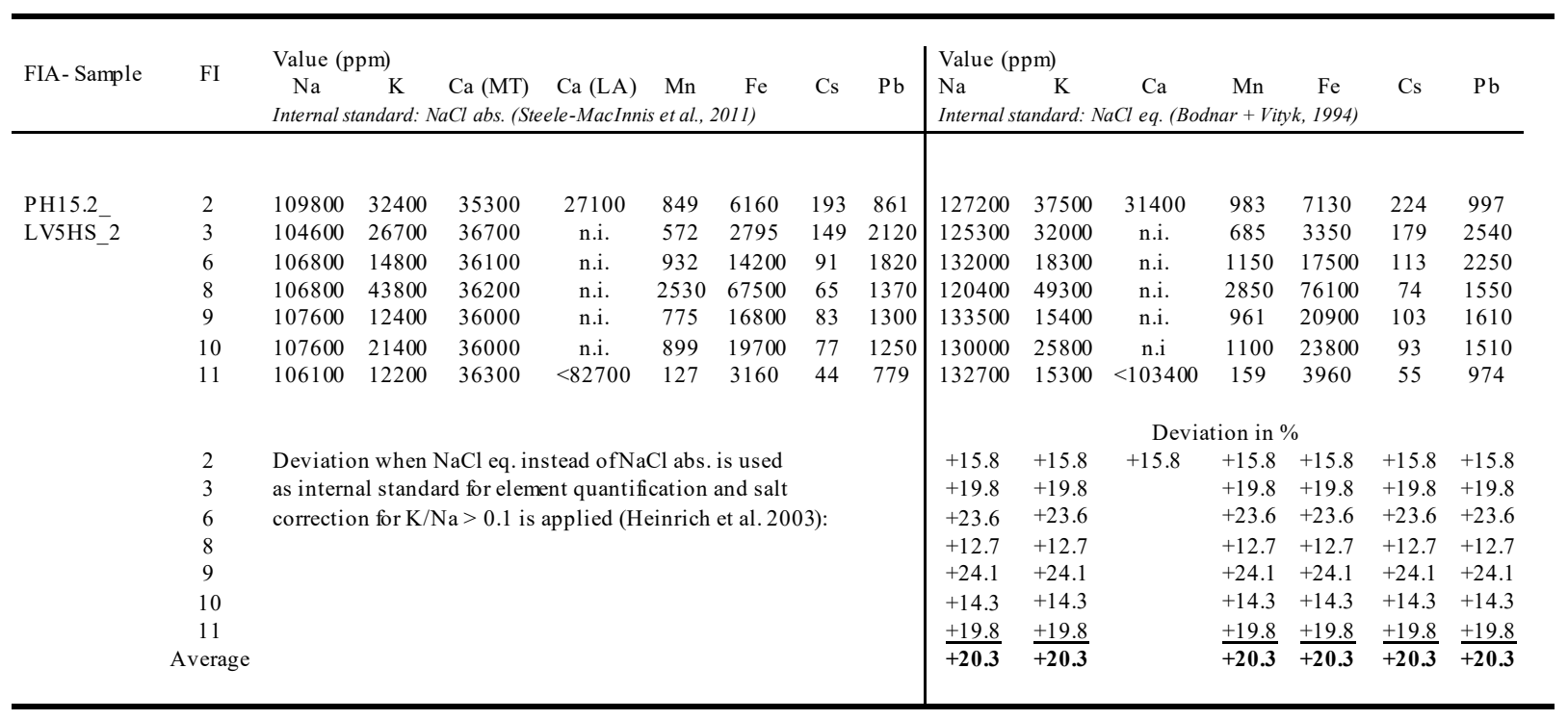

\subsection{Independent Ca analysis by LA-ICPMS}

In principle, the $\mathrm{Ca} /(\mathrm{Na}+\mathrm{Ca})$ ratio can be independently measured by microthermometry as well as LA-ICPMS. However, the quantification of Ca by LA-ICPMS is imprecise because of the high background on mass ${ }^{40} \mathrm{Ca}$ and ${ }^{42} \mathrm{Ca}$ caused by the Argon plasma, limiting signal/noise ratio especially when analysing smaller FI (Fig 5). The alternative isotope ${ }^{44} \mathrm{Ca}$ overlaps with ${ }^{28} \mathrm{Si}^{16} \mathrm{O}$, which may cause systematic errors that we have not yet explored. Figure 6 illustrates the scatter among individual FI from the same FIA, showing that $\mathrm{CaCl}_{2}$ and $\mathrm{NaCl}$ concentrations can be more precisely determined by careful microthermometry than by LA-ICPMS. Figure 6 and Table 3 also show that due to the high background on mass 42, only 17 FI in 6 assemblages (from a total 45 FI in 10 assemblages measured with microthermometry) allowed Ca quantification using significant LA-ICPMS signals on mass ${ }^{42} \mathrm{Ca}$. Thus, almost $2 / 3$ of the inclusions analysed in this study would not have shown detectable Ca concentrations by LA-ICPMS, even though microthermometry clearly show Ca to be a major component. Nevertheless, among those FI where Ca was detected by LA-ICPMS, most of the Ca concentrations computed from the small ${ }^{42} \mathrm{Ca}$ signal are consistent with the more precise $\mathrm{Ca}$ concentration determined by microthermometry, with random deviations of mostly less than $10 \%$ (Fig. 6 and Table 3). 

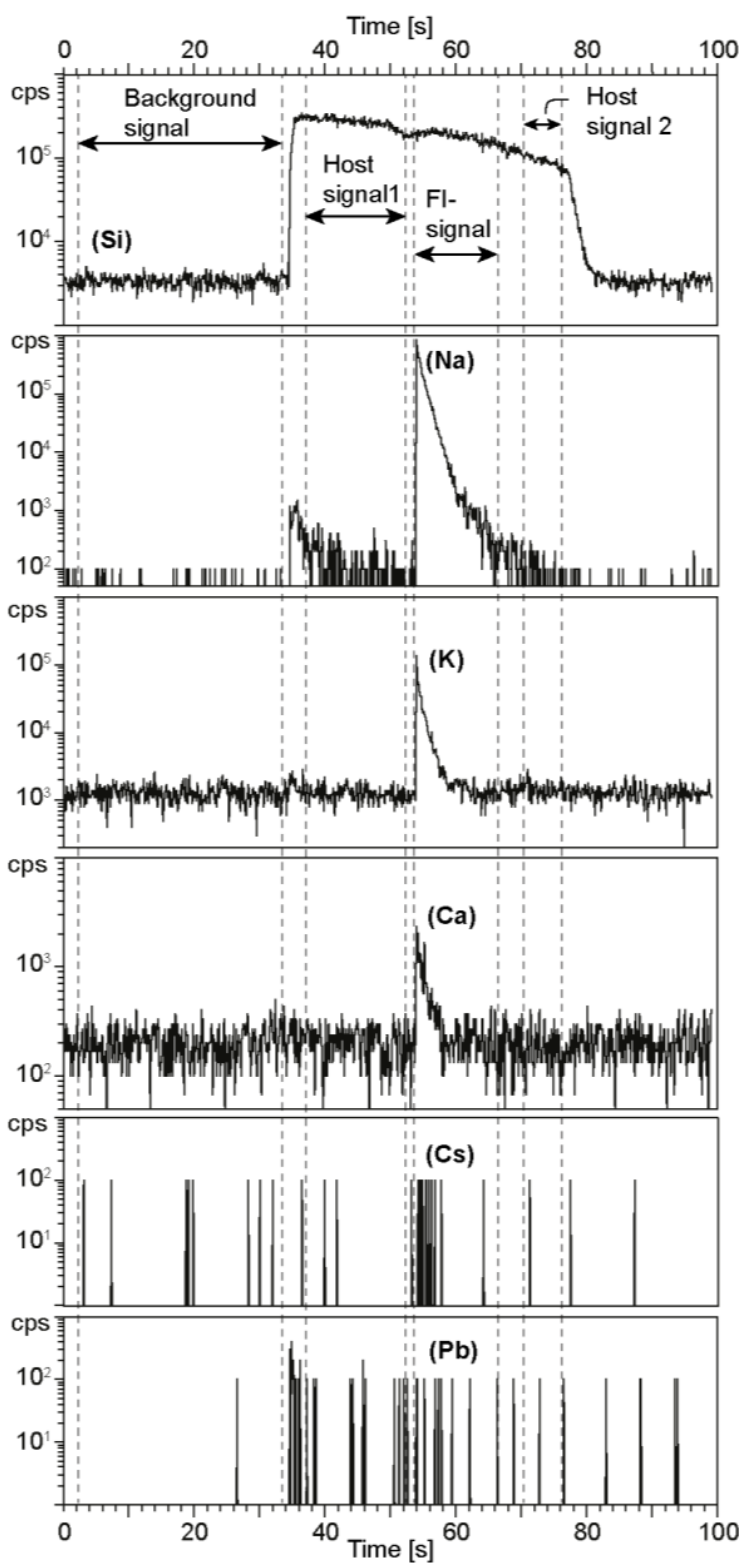

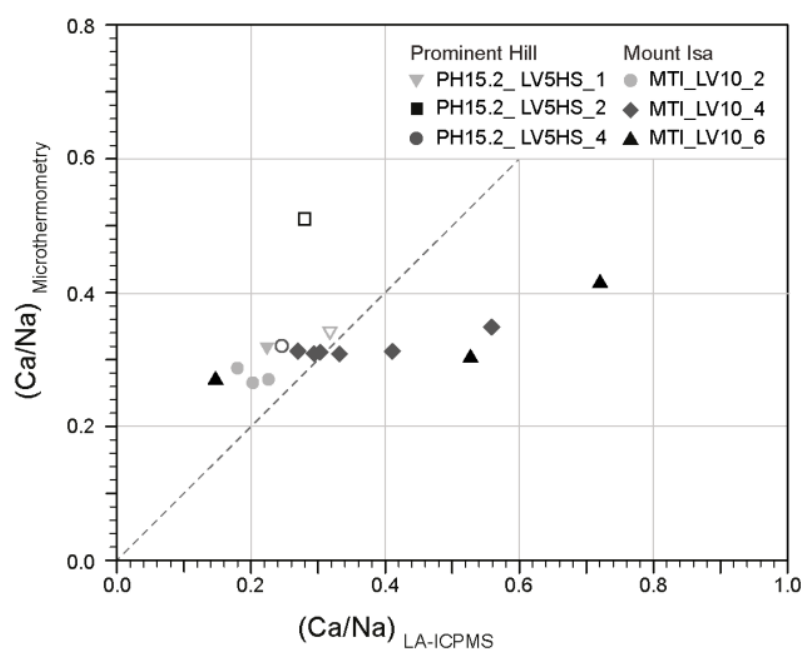

Figure 5. $\mathrm{Ca} / \mathrm{Na}$ ratios of single fluid inclusions for six FIA determined by microthermometry show minimal variation within one assemblage, compared to ratios determined by LA-ICPMS Open symbols indicate FI within an assemblage where microthermometry measurements required one average phase melting temperature (either ice, hydrohalite or halite) of the other inclusions in the same FIA to determine the inclusions salinity. All other symbols represent inclusions for which both melting temperatures were observed and measured directly.

Figure 6. Transient LA-ICPMS signal illustrating the signal for selected elements in counts per second (cps) versus time, and the separation of this time-resolved signal into its component parts (background, host, inclusion). Note the relatively poor $42 \mathrm{Ca}$ /background intensity ratio obtained by LA-ICPMS due to the low elemental abundance of $42 \mathrm{Ca}$ $(0.67 \%)$.

\section{Conclusion}

Microthermometric measurement of two phase transitions allows absolute $\mathrm{CaCl}_{2}$ and $\mathrm{NaCl}$ quantification in Ca-Na-dominated brine inclusions. This approach is applicable to obtaining Na concentration as internal standard for LA-ICPMS quantification, irrespective of the host mineral, i.e., quartz or a Ca-rich minerals like fluorite or carbonate where the host background makes LA-ICPMS measurement of Ca impossible. Our tests showed that observed ranges of phase melting temperatures are small within petrographically well-defined fluid inclusion assemblages, resulting in a narrow $\mathrm{Ca} /(\mathrm{Ca}+\mathrm{Na})$ range. Therefore, even one or a few complete microthermometry data sets comprising measurement of the two last-melting phases (hydrohalite and either ice or halite), and applying these results as internal standard to all inclusions of an assemblage, will generally be a significant improvement compared with simply using wt\% $\mathrm{NaCl}$ eq. as an internal standard for LA-ICPMS quantification of sodic-calcic brines. Given that Ca is difficult to analyse by LA-ICPMS due to high background and/or low abundance sensitivity on all masses of $\mathrm{Ca}$, careful microthermometry and application of phase relations in the ternary $\mathrm{H}_{2} \mathrm{O}-\mathrm{NaCl}-\mathrm{CaCl}_{2}$ system is superior to any empirical correction for additional salt components in analyzing fluid inclusions of sodic-calcic brines. 


\section{Acknowledgements}

This project was made possible by funding from the Swiss Science National Funds (SSNF) project no. 200020-135302/1 and the Institute of Geochemistry and Petrology of the Swiss Federal Institute of Technology Zürich (ETH Zurich). We thank Thomas Good for the excellent preparation of fluid inclusion wavers. Special thanks go to OZ Minerals Ltd for providing access and substantial contribution during field work at Prominent Hill mine site. Financial support for Steele-MacInnis was provided by the Institute for Critical Technology and Applied Science (ICTAS) at Virginia Tech, and by the U.S. National Science Foundation (NSF) under grant no. OCE-0928472 to R. J. Bodnar. We finally thank Thomas Pettke from the University of Bern for his constructive and critical review.

\section{References}

Allan, M.M., Yardley, B. W. D., Forbes, L. J., Shmulovich, K. I., Banks, D. A., Shepherd, T. J., 2005. Validation of LA-ICP-MS fluid inclusion analysis with synthetic fluid inclusions. American Mineralogist, 90(11-12): 1767-1775.

Baker, T., Mustard, R., Fu, B., Williams, P.J., Dong, G.Y., Fisher, L., Mark, G., Ryan, C.G., 2008. Mixed messages in iron-oxide copper-gold systems of the Cloncurry district, Australia: Insights from PIXE analysis of halogens and copper in fluid inclusions. Mineralium Deposita, 43(6): 599-608.

Bertelli, M., Baker, T., 2010. A fluid inclusion study of the Suicide Ridge breccia pipe, Cloncurry district, Australia: Implication for breccia genesis and IOCG mineralization. Precambrian Research, 179(1-4): 69-87.

Bodnar, R.J., Vityk, M.O., 1994. Interpretation of microthermometric data for $\mathrm{H}_{2} \mathrm{O}-\mathrm{NaCl}$ fluid inclusions. In: Fluid Inclusions in Minerals, Methods and Applications, B. De Vivo and M. L. Frezzotti, eds., pub. by Virginia Tech, Blacksburg, VA, 117-130 pp.

Bottomley, D.J., Katz, A., Chan, L.H., Starinsky, A., Douglas, M., Clark, I.D., Raven, K.G., 1999. The origin and evolution of Canadian Shield brines: Evaporation or freezing of seawater? New lithium isotope and geochemical evidence from the Slave craton. Chemical Geology, 155(3-4): 295-320.

Davidson, G.J., Paterson, H., Meffre, S., Berry Ron, F., 2007. Characteristics and origin of the Oak Dam East breccia-hosted, iron-oxide $\mathrm{Cu}-\mathrm{U}-(\mathrm{Au})$ deposit; Olympic Dam region, Gawler Craton, South Australia. Economic Geology, 102(8): 1471-1498.

Derome, D., Cathelineau, M.,Cuney, M., Fabre, C., Lhomme, T., Banks, D.A., 2005. Mixing of sodic and calcic brines and uranium deposition at McArthur River, Saskatchewan, Canada: A Raman and laser-induced breakdown spectroscopic study of fluid inclusions. Economic Geology, 100(8): 1529-1545.

Derome, D., Cuney, M., Cathelineau, M., Fabre, C., Dubessy, J., Bruneton, P., Hubert, A., 2003. A detailed fluid inclusion study in silicified breccias from the Kombolgie sandstones (Northern Territory, Australia): Inferences for the genesis of middle-Proterozoic unconformity-type uranium deposits. Journal of Geochemical Exploration, 80(2-3): 259275.

Dilles, J.H., Einaudi, M.T., 1992. Wall-rock alteration and hydrothermal flow paths about the AnnMason porphyry copper-deposit, Nevada - a 6-km vertical reconstruction. Economic Geology, 87(8): 1963-2001.

Fritz, P., Frape, S.K., 1982. Saline groundwaters in the Canadian Shield a 1st overview Chemical Geology, 36: 179-190.

Goldstein, R.H., Reynolds, T.J., 1994. Systematics of fluid inclusions in diagenetic minerals. SEPM Short Course 31. 213 pp.

Günther, D., Audetat, A., Frischknecht, R. Heinrich, C. A., 1998. Quantitative analysis of major, minor and trace elements in fluid inclusions using laser ablation-inductively coupled plasmamass spectrometry. J. Anal. At. Spectrom, 13(4): 263 - 270. 
Guillaume, D., Teinturier, S., Dubessy, J., Pironon, J., 2003. Calibration of methane analysis by Raman spectroscopy in $\mathrm{H}_{2} \mathrm{O}-\mathrm{NaCl}-\mathrm{CH}_{4}$ fluid inclusions. Chemical Geology, 194(1-3): 4149.

Guillong, M., Meier D., L., Allan M. M., Heinrich, C.A., Yardley, B.W.D., 2008. Appendix A6; SILLS; a MATLAB-based program for the reduction of laser ablation ICP-MS data of homogeneous materials and inclusions. Short Course Series Mineralogical Association of Canada, 40: 328-333.

Haynes, F.M., 1985. Determination of fluid inclusion compositions by sequential freezing. Economic Geology, 80(5): 1436-1439.

Haynes, F.M., Kesler, S.E., 1987. Chemical evolution of brines during Mississippi Valley-type mineralization: Evidence from East Tennessee and Pine Point. Economic Geology, 82(1): 53-71.

Heinrich, C.A., Andrew, A.S., Wilkins, R.W.T., Patterson, D.J., 1989. A fluid inclusion and stable isotope study of synmetamorphic copper ore formation at Mount Isa, Australia. Economic Geology, 84(3): 529-550.

Heinrich, C.A. et al., 1995. Fluid and mass-transfer during metabasalt alteration and copper mineralization at Mount Isa, Australia. Economic Geology, 90(4): 705-730.

Heinrich, C.A., Pettke, T., Halter, W.E., Aigner-Torres, M., Audétat, A., Günther, D., Hattendorf, B., Bleier, D., Guillong, M., Horn, I., 2003. Quantitative multi-element analysis of minerals, fluid and melt inclusions by laser-ablation inductively-coupled-plasma massspectrometry. Geochimica Et Cosmochimica Acta, 67(18): 3473-3497.

Heinrich, C.A., Ryan, C.G., Mernagh, T.P., Eadington, P.J., 1992. Segregetion of ore metals between magmatic brine and vapor- a fluid inclusion study using PIXE microanalysis. Economic Geology, 87(6): 1566-1583.

Klemm, L.M., Pettke, T., Heinrich, C.A., Campos, E., 2007. Hydrothermal evolution of the El Teniente deposit, Chile: Porphyry Cu-Mo ore deposition from low-salinity magmatic fluids. Economic Geology, 102(6): 1021-1045.

Longerich, H.P., Jackson, S.E., Günther, D., 1996. Laser ablation inductively coupled plasma mass spectrometric transient signal data acquisition and analyte concentration calculation. Journal of analytical atomic spectrometry, 11: 899-904

Lowenstein, T.K., Hardie, L.A., Timofeeff, M.N., Demicco, R.V., 2003. Secular variation in seawater chemistry and the origin of calcium chloride basinal brines. Geology, 31(10): 857-860.

Mark, G., Williams P.J., Oliver N.H.S., Ryan, C., Mernagh, T., 2005. Fluid inclusion and stable isotope geochemistry of the Ernest Henry Fe oxide-Cu-Au deposit, Queensland, Australia. Proceedings of the Biennial SGA Society for Geology Applied to Mineral Deposits Meeting. 8, Vol. 1: 785-788.

McKibben, M.A., Andes, J.P., Williams, A.E., 1988. Active ore formation at a brine interface in metamorphosed deltaic lacustrine sediments-The Salton Sea geothermal system, California. Economic Geology, 83(3): 511-523.

Mercadier, J., Richard, A., Boiron, M.C., Cathelineau, M., Cuney, M., 2010. Migration of brines in the basement rocks of the Athabasca Basin through microfracture networks (P-Patch U deposit, Canada). Lithos, 115(1-4): 121-136.

Mernagh, T.P., Heinrich, C.A., Leckie, J.F., Carville, D.P., Gilbert, D.J., Valenta, R.K., Wyborn, L.A.I., 1994. Chemistry pf low- temperature hydrothermal Gold, Platinum, and Palladium (+/Uranium) mineralization at Coronation Hill, Nothern-Territory, Australia. Economic Geology, 89(5): 1053-1073.

Mernagh, T.P., Wilde, A.R., 1989. The use of the laser Raman microprobe for the determiention of salinity in fluid inclusions Geochimica et Cosmochimica Acta, 53(4): 765-771.

Oreskes, N., Einaudi, M., T., 1992. Origin of hydrothermal fluids at Olympic Dam; preliminary results from fluid inclusions and stable isotopes. Economic Geology, 87(1): 64-90.

Richardson, C.K., Pinckney, D.M., 1984. The chemical and thermal evolution of the fluids in the Cave-in-rock fluorspar district, Illinois- mineralogy, paragenisis and fluid inclusions. Economic Geology, 79(8): 1833-1856. 
Robert, F., Kelly, W.C., 1987. Ore-forming fluids in Archean gold-bearing quartz veins at the Sigma Mine, Abitibi greeenstone belt, Quebec, Canada. Economic Geology, 82(6): 14641482.

Schiffries, C.M., 1990. Liquid-absent aqueous fluid inclusions and phase-equilibria in teh system $\mathrm{CaCl}_{2}-\mathrm{NaCl}-\mathrm{H}_{2} \mathrm{O}$. Geochimica et Cosmochimica Acta, 54(3): 611-619.

Schmidt Mumm, A.S., Wolfgramm, M., 2004. Fluid systems and mineralization in the north German and Polish basin. Geofluids, 4(4): 315-328.

Shelton, K.L., Bauer, R.M., Gregg, J.M., 1992. Fluid inclusion studies of regionally extensive epigenetic dolomites, Bonneterre dolomite (Cambrian), Southeast Missouri- evidence of multiple fluids during dolomitization and lead-zinc mineralization. Geological Society of America Bulletin, 104(6): 675-683.

Shepherd, T.J., Bouch, J.E., Gunn, A.G., McKervey, J.A., Naden, J., Scriver, R.C., Styles, M.T., Largr, D.E., 2005. Permo-Triassic unconformity-related Au-Pd mineralisation, South Devon, UK: New insights and the European perspective. Mineralium Deposita, 40(1): 24-44.

Steele-MacInnis, M., Bodnar, R.J., Naden, J., 2011. Numerical model to determine the composition of $\mathrm{H}_{2} \mathrm{O}-\mathrm{NaCl}-\mathrm{CaCl}_{2}$ fluid inclusions based on microthermometric and microanalytical data. Geochimica et Cosmochimica Acta, 75(1): 21-40.

Stoffell, B., Appold, M.S., Wilkinson, J.J., McClean, N.A., Jeffries, T.E., 2008. Geochemistry and evolution of Mississippi Valley-type mineralizing brines from the Tri-State and Northern Arkansas Districts determined by LA-ICP-MS microanalysis of fluid inclusions. Economic Geology, 103(7): 1411-1435.

Vanko, D.A., 1988. Temperature, pressure, and composition of hydrothermal fluids, with their bearing on the magnitude of tectonic uplift at mid-ocean ridges, inferred from fluid inclusions in oceanic layer-3 rocks. Journal of Geophysical Research-Solid Earth and Planets, 93(B5): 4595-4611.

Vanko, D.A., Griffith, J.D., Erickson, C.L., 1992. Calcium-rich brines and other hydrothermal fluids in fluid inclusions from plutonic rocks, Oceanographer Transform, Mid-Atlantic Ridge. Geochimica et Cosmochimica Acta, 56(1): 35-47.

Wilde, A.R., Mernagh, T.P., Bloom, M.S., Hoffmann, C.F., 1989. Fluid inclusion eveidence on the origin of some Australian unconformity-related deposits. Economic Geology, 84(6): 1627-1642.

$\mathrm{Xu}, \mathrm{G} ., 2000$. Fluid inclusions with $\mathrm{NaCl}-\mathrm{CaCl}_{2}-\mathrm{H}_{2} \mathrm{O}$ composition from the Cloncurry hydrothermal system, NW Queensland, Australia. Lithos, 53(1): 21-35.

Yanatieva, O.K., 1946. Solubility polytherms in the systems $\mathrm{CaCl}_{2}-\mathrm{MgCl}_{2}-\mathrm{H}_{2} \mathrm{O}$ and $\mathrm{CaCl}_{2}-\mathrm{NaCl}_{-} \mathrm{H}_{2} \mathrm{O}$. Zhurnal Obshchei Khimii, 19: 709-722.

Zwart, E.W., Touret, J.L.R., 1994. Melting behavior and composition of aqueous fluid inclusions in fluorite and calcite - applications within the system $\mathrm{H}_{2} \mathrm{O}-\mathrm{CaCl}_{2}-\mathrm{NaCl}$. European Journal of Mineralogy, 6(6): 773-786. 